\title{
The Successor Training as a Success Factor in the Management and Continuity of the Family Business
}

\section{Luz del Carmen García Arroyo \\ Interdisciplinary College of Specialization, Puebla, Mexico}

\section{Montserrat Gómez-Márquez}

Higher Technological Institute of Huatusco, Mexico

\section{Martha Patrícia Quintero- Fuentes}

Interdisciplinary College of Specialization, Puebla, Mexico

\section{Manuel González-Pérez}

Interdisciplinary College of Specialization, Puebla, Mexico

Submitted: 16 October 2020

Accepted: 24 November 2020

Published: 30 November 2020

Corresponding author:

Luz del Carmen García Arroyo

DOI: 10.19044/esj.2020.v16n31p345

(c) Copyright 2020 Aafaf Essedaoui et al. Distributed under Creative Commons BY-NC-ND 4.0 OPEN ACCESS

\section{Abstract}

The formation of the successor is a process that begins at home from an early age, and its main objective is to preserve the family legacy and keep the company's administration in the hands of the family. The family business's continuity depends mainly on the training received by their predecessors' successors to replace them in business management when retirement them. A descriptive and cross-sectional study was carried out that identified the influence of the successors' formation to achieve success in business management and the family business's continuity. This study collected data from 15 family businesses located in southeastern Mexico. The data collection instrument used was a closed-order questionnaire that was validated using Pearson's correlation. The chi-square test of statistical independence generates the calculation of the dependency between the variables studied. The theoretical chi-square graph is the pair of variables that make up the hypothesis and its theoretical inverse function: $p$-value $=0.05$ vs. chi-square of 1 degree of freedom to observe the intersection. In conclusion, the statistical tests yielded six variables more dependent on each other. Items three and four, four and one, and two and seven associated with $95 \%$ reliability in theoretical or critical chi and $100 \%$ reliability in observed or experimental chi. Therefore, these results found are statistically significant. It observed that the training of successors influences business management's success and the family business's continuity. This hypothesis verified an observed or experimental chi value of 5.2387 and a theoretical or critical chi of 3.8415 .

How to cite this article

Arroyo G. et al, (2020). The Successor Training as a Success Factor in the Management and Continuity of the Family Business. European Scientific Journal, ESJ, 16(31), 345. https://doi.org/10.19044/esj.2020.v16n31p345 
Subject: Management

Keywords: Successor Training, Family Business, Management, Continuity

\section{Introduction}

Family businesses are complex organizations that face their main challenge during the succession process; when this phenomenon occurs, a high percentage of them disappear, unable to survive the next generation. Various factors such as the lack of a strategic plan, the creation of a family protocol, the adoption of corporate and institutional governance, and successors' election to successfully replace leadership positions affect its continuity.

The family business succession plan involves the family reaching agreements about the future they want for the business. The future of the family business does not depend solely on blood ties. Therefore, the family must build a shared vision with the participation of all its members. This vision contributes to the successor's formation to maintain and make the family business grow, valuing its predecessors' legacy beyond the economic benefits since it is a joint family dream.

During the generational transfer, the family business's problem must be approached, considering its three main elements: family, business, and property. The owner's family must follow a protocol created by itself, which contains the game rules to resolve conflicts that may arise in the relation between the family and the business and regulate access to family members in the administration, control, and direction of the business company.

These companies are generally led by the owners, who are characterized by filling the jobs without evaluating the family candidates' competencies. Generational transmission is different for each family business; since each family has its peculiarities and characteristics. In the findings of items four and one; in the strategic plan for the continuity of the family business, it is vitally important to consider management through corporate, institutional governance, which regulates business management by family members with appropriate values and skills.

The generational change complexity increases when the founder's retirement arrives and, consequently, his successor's election. This election represents one of the most difficult decisions to face in managing the founding shareholders because they frequently lack suitable candidates. The absence of candidates is due, in many cases, to inadequate training for potential successors. In the development of this research, it was identified in items three and four that the founders of family businesses that prepare their successors to replace them also implement corporate, institutional governance that contributes to their permanence. Therefore, the selection of suitably trained successors is crucial to achieving successful replacement in the leadership position. 
The formation of the successor is a task that begins from childhood through the teachings and attitudes of parents about the family business; in this stage, the successor learns and develops the values that will strengthen him as the leader of the family business. During the training process, the successor gains skills that enhance his confidence and creativity. Hard skills, soft skills, and experience are competencies that the successor must develop before taking the family business's leadership.

Another finding found in items two and seven of this study refers to institutional family businesses where the administration is in charge of personnel with adequate training and knowledge. Family businesses are organizations characterized by the critical influence that the family exerts on the company; Therefore, the main objective in forming a successor is to preserve the family legacy and keep the business management in the family's hands. The company's continuity depends mostly on the training received by their predecessor's successor to replace him when he decides to retire and hand over the baton.

This research identified that the successor's formation influences business management's success and the family business's continuity. Furthermore, in this study, it was found that the strategic plan of the family business considers corporate governance to achieve its permanence and that the founders of family businesses who prepare their successors to replace them also implement an institutional corporate governance. Finally, we identify that in institutional family businesses, the administration is in charge of personnel with adequate training and knowledge.

\section{Successor Training in Family Businesses}

The family business is an institution controlled by a family and where two or more members of it are involved in its operation (Belausteguigoitia, 1996). This type of company presents its main problem when it comes time for succession. Nonetheless, the conflicts that arise during the succession process distinguished by creating a legacy (Tápies, 2011).

The generational transfer is a process poorly known by its protagonists: parents and children. Despite being its potential successors, parents do not discuss this matter with their children due to their lack of experience (González, Benítez \& Tamayo, 2017). Notwithstanding, family members feel proud of the company (Gutiérrez, Gómez, Beas \& Ortega, 2018). This transfer is a delicate process that begins with the founding entrepreneur's retirement future successor's appointment. This appointment is generally for the firstborn, without being subject to an evaluation of the skills required for the position, and if he or she is the person who will successfully lead the family business in the coming years (Araya, 2011). 
Some authors, such as Leach (1993) and Gallo (1995), refer to the succession process as a simple baton transfer. Other authors such as Ward (1988) and Gallo (1998), and Leandro (2017), agree that the succession's arrival is much more bearable when the company begins to carry out strategic planning. According to Vassiliadisa, Siakasb, \& Vassiliadisc (2015), generational handover is crucial in the family company's life cycle due to ownership and leadership transfers. While Brenes, Madrigal \& Molina (2006) bases the premise that management and organizational structure must address vital issues to ensure family business continuity.

Leadership is a vital issue that these companies must manage to ensure their continuity; Despite this, most of them disappear during the succession process due to the absence of a continuity plan to replace the leadership position (Durán, 2019). In family businesses, $45 \%$ of leaders are over 60 years of age, which shows that retirement does not depend on reaching old age and that the founders only decide to "leave" (IPADE, 2019).

During the generational transfer, it is easy to hurt sensitivities since the new leader's election is detrimental to other candidates. Therefore, success in succession requires strategic planning; if it is left the replacement for the last moment, this will doom to disaster either due to haste, due to decisions made at an inappropriate time, or because the candidates are not prepared (Tápies, 2011).

The lack of a successor training plan is an aspect that stands out in the generational transfer of these organizations (Gutiérrez et al. 2018). For example, Quejada, Gutiérrez \& Nelson (2016) mention the confusion that the successors show during this process to distinguish the family's functions and the organization. When planning the successor's formation, it is essential to know the dreams, motivations, and competencies of the potentials successors and the company's needs; do not consider family members' interests often leads to failure (Belausteguigoitia, 2013). The socio-cultural aspects must also consider because the successor must prioritize the company or the family (Basurto \& Campos, 2017).

Precisely in the "Training for the future" lies a large part of the success of Family Businesses. Hence their members must train with knowledge and values, and future leaders must follow a versatile, logical, and above all planned career plan (Tapies, 2011). Authors such as Gallo (1998), Posso (2008), and Schlepphorst \& Moog and Gaona, de la Garza \& Hernández (2014), Visser and Fuad, Sudarma \& Irianto (2019) have studied the formation of the successors from different approaches.

According to Gallo (1998), in developing a person's capacity to become the chief executive officer of a family business, three stages can distinguish. The "remote" preparation, "proximate" preparation, and "on-site" (immediate) preparation stages. For Posso (2008), the successor's formation is 
a stage made up of three dimensions and five influential elements. While Schlepphorst \& Moog (2014) address the requirements that family successors must meet to be considered adequate from three perspectives. Gaona et al. (2018) studied that the successor's formation will depend on the time and effort that the founder dedicates to this critical task. The continuity of the family business depends on adequately educating the successors, instilling values , and attitudes. At the same time, Visser (2019) focuses his study on the successor leader's external training. For their part, Fuad et al. (2019) mention that open communication between founders and successors is key to intergenerational transfer's success.

Gallo (1998) considered the most outstanding researcher on the subject of Spanish family businesses, addresses the formation of the successor of the family business from three stages of preparation:

1) The remote preparation stage occurs in the childhood and adolescence of the successor, up to 18 years of age; this stage develops under two premises: "to know to love" and "practice work." The premise "to know to love" is based on the fact that human beings can only love what they know, and if they love, they will continue in the effort to learn more to get to love even better. The successor knows what his family business will one day be through the conversations between the predecessor and his spouse. The premise "practice work" refers to carrying out activities in the family business, to have the opportunity to increase human virtues and affection for the company.

2) In the proximate preparation stage, it is advisable for the successor to carry out part of his studies in other regions and countries, with the logical premises of learning other languages. With this same purpose, during their university studies, successors should be encouraged and helped carry out part of the internship activities in companies that do not belong to their family and even in companies outside the country, always promoting openness in acquiring experience new knowledge.

3) Finally, in the immediate preparation stage, it must take into account that the appropriate date for incorporating the family business's successor does not only depend on the completion of their university studies. The predecessor's age also influences the fact that the successor works in another company for a few years, which allows him to "look outside," acquire greater self-confidence and superior prestige in front of unfamiliar managers and front of other members of the family.

Bringing on a successor who has gone through the "remote," "upcoming," and "immediate" stages of readiness is equivalent to hiring a young man with skills and opportunities to become a member of the senior 
management team in the short term. However, incorporating a successor presents certain peculiarities since he is a young man destined to become a family business leader.

Posso (2008) investigated that in four Colombian family businesses, the formation of the successor means having better elements that allow successors to see the three dimensions of training with their five influential elements and define clear goals without inhibiting their interests and ignoring the area immerse. In the three dimensions of formation of successors, values such as honesty, respect, hard work, perseverance, independence, love for the product, the desire for the best for the work team were found by Lambrech (2005), as values that transmitted in the family business in the childhood and youth of the sons.

Leadership training can come from individual initiative, the day-to-day relationship with the predecessor, and the family-business system's internal and external environment through activities that help develop self-confidence, independence, and resilience (Drennan, Kennedy \& Renfrow, 2005). The exterior work experience contributes to gradually reducing the child's dependence on the father and gaining self-confidence, which is forging a more autonomous behavior on the descendant's part, which favors their formation as a leader. Training in values and training in leadership skills should complement by training in administrative areas or in an entire technical area: formal education that gives skills to the potential successor of working in the family business.

Schlepphorst \& Moog (2014) analyzed various German family businesses; these authors found that hard skills are a necessary but insufficient attribute for suitable successor candidates as soft skills are highly valued.To understand the family's succession requirements often leaves potential successors in the dark regarding their expectations; therefore, descendants may need to guess what attributes they should contribute to the company.

The requirements to correctly choose the successor follows a systematic order and ranking of importance associated with expected predecessor abilities that closely overlap with academic recommendations. The process of recruiting and selecting family successors must be systematic and well-considered, taking into account two pre-selection processes, assessment, recruitment channels, and finally, the successor's selection.

This systematic process follows a series of steps, (1) Pre-selection of successors consists of continuous monitoring of descendants interested in the private and business sphere. (2) Verification of succession needs and informal analysis of job profiles and requirements. (3) Pre-selection of eligible successors, in this step, a communication channel is opened to exchange personal dialogues with possible successors. (4) The successor's selection, capacitation, and training focus on leadership, and his integration to the 
company is gradual. The personal goals must coincide with the opportunities to enter the family business. (5) Constant feedback on the expectations of the predecessor and the abilities and attitudes of the successor. To conclude the selection process, negotiation dialogues must open to the signing of an employment contract in a senior management position.

Gaona et al. (2014) interviewed eight founders of family businesses in Mexico, who stated that the formation of the successor would depend on the time and effort that the founder dedicates to this vital task and that the business continuity of the family depends on adequately educating the successors, inculcating values and attitudes.

The founder's figure has a complex and unique influence on children's emotional and intellectual development: love, example, values, and discipline are fundamental elements that the founder transmits so that the successor becomes the right person. These elements help develop healthy self-esteem that contributes to the security of the future successor.

The training that family members receive must be comprehensive and inclusive to ensure that they are on the right path, that all members agree on the founder's decisions. Identifying the successor is a process that involves a series of aspects that develop gradually; the founder must know the desired profile of the successor, who is capable of meeting the needs of the company and the demands of the family.

The successor's formation within the family business is not limited to an academic degree; it is a life-long process. The successor will develop skills like leadership, planning, organization, acceptance of the position, interest in the company, external work experience, communicating his objectives, solving problems, and decision-making. These skills are necessary to fill a position that does not yet exist, and it will be created in an age that no one can safely foresee.

The relationship between father and son is the best system to educate and promote business values and inspire and involve them for their future incorporation into the family business. The candidate will receive training according to the company's needs, gain experience in other companies, interact with the staff, and know that they will be the leader of the company very soon. The external experience helps to identify if they can face the challenge or give up. On the other hand, the founder must understand that a transition cannot be forced when the required conditions do not exist. Perhaps neither of the children has the ability or interest to run the business.

Visser (2019) focuses his study on the successor leader's external training. This author conducted his research in two Swedish companies and two German companies, identifying that the founder leader significantly affects the successor, except when the successor has had training elsewhere with an external organizational culture. In this case, experience the external 
workforce and exposure to other organizational cultures significantly impact business leadership and how the new leader will shape the family business's organizational culture.

This author developed a timeline model with five essential elements; the model will incorporate the factor of external experience acquired by the successor in the incumbent leader's succession plan; these three elements result in the development of business leaders and organizational culture.

The findings found in this research indicate that the founder leader's leadership style has less effect on the successor generations' leadership style when these generations have acquired work experiences outside the family business.

The main influences on the timeline of a founding leader are the experiences that successors gain outside of the family business. External formation contributes to a more personalized leadership style in the successor. Simultaneously, successors with no external experiences adopt a leadership style identical or similar to their predecessor. This adoption of a leadership style similar to the predecessor affects the lack of organizational culture and business leadership development. As the timeline continues, the model switches to succession planning.

The model ends and is repeat with the transfer of leadership from the incumbent to the next generation. At this point, the next generation has gained experience before or during their incorporation into the succession plan.

In scenarios where the baton's handover is awarded to a successor without external training, the new leader adopts his predecessors' leadership style, resulting in a lack of organizational change, continuing the traditional corporate values adopted from his predecessors. The generation joins the succession plan, repeating the cycle.

Fuad et al. (2019) mention that open communication between founders and successors is key to intergenerational transfer success. These authors identified three fundamental obstacles that successors must face in Indonesia during the family business's intergenerational transition process. To overcome them, es indispensable an intense communication between the successors and predecessors and between the successors themselves.

The first hurdle refers to the "founder's trap," that is, the older generation's reluctance or their predecessors to hand over the company's management entirely to the next generation and act more as advisers. The second obstacle is "sibling rivalry," that is, the successors' reserve to actively participate in the family business management due to the fear they feel about the conflicts that may arise between them. Finally, the third obstacle is the "passion of the next generation". This obstacle refers to the founders' concern that their children do not have enough passion or enthusiasm to continue running the family business. 
Successors must recognize these obstacles in advance to provide a positive contribution to the sustainability of the family business and adapt to changes in the business environment and help the intergenerational transition process take place whit out smoothly.

In the generational transfer, good communication between the main actors (predecessor and successor) is essential to overcome problems. Also, it is necessary to consider external parties' assistance, such as consultants who are mediators of the process.

The communication process is not easy to achieve in a country like Indonesia. In their cultural heritage, children do not disagree with their parents or younger siblings with older siblings. However, the succession process requires healthy discussions to create open communication between the founders and successors. In this case, the "discussion at the dining room table" is considered beneficial in implementing the succession process that helps to achieve the family business's continuity; in this culture, the mother's role as a mediator is significant.

For several years the succession was presented as a static event when it must treat as a process (Davis \& Harveston, 1998). Ward (1994) points out that this training process has to start at home, taught directly, and through parents' behavior during their children's childhood. Then she must continue with her education at school and with her first contacts with the family business. Subsequently, the family business's connection should increase their leadership skills and motivate their experience outside the family business. The father-son succession in the leadership of a company controlled by a family involves a long-term, diachronic socialization process. The successor member is gradually preparing for administration through learning experiences (Longenecker \& Schoen, 1978).

According to Walsh (2011), the future successor must enter as a candidate to assume the family business's management, with well-defined functions that contribute to the company's general operation. In choosing the successor, guidelines such as age, education, and experience are indispensable that the family members enter the business. This means that a son or daughter may have to work in another business for some time or receive specific training for the job he or she will be doing.

Candidates must succeed the leader with well-defined roles and responsibilities because if there is the feeling that the successor is chosen only because of her family situation and not because of her abilities, her credibility will be diminished, affecting the spirit of the company. Internal managers who tend to see themselves as potential successors may go against the successor (Hollerbach, 2012).

The choice of successor does not necessarily have to do with the firstborn or the one who does not find a job. The founder of Bimbo declares that 
he chose as his successor, the youngest of their eight sons, because: he is a person with a privileged mind and has turned out to be an excellent and timely director of the group. Since he was a child it was brilliant, possessor of order and intelligence; he was eight or nine years old when he did his work schedules for the day, and he had the hours to get ready, play, read, and to my surprise, he had left a space of his time to think. When choosing his professional career, he said: "I know Dad that I have a responsibility to you and to the business you built, I will prepare to fulfill it; this was a joy for a father and a value for our company (Cherem, 2008).

The family business's succession is not always accompanied by a strategic plan to achieve its continuity; in many cases, the presence of an event accelerates this succession and leading the successor to receive the baton without adequate training. Such is the subject of Corporación Cefa, SA; after that, the founder's death, his successor, Denisse Garnier, took the reins without any continuity plan, facing the moral commitment he felt with the family business legacy. Garnier affirms that "the success in continuity I owe to the work team that I inherited and to my work experience in national and international companies" (Pymes, 2014).

\section{Methodology}

A descriptive and cross-sectional study was carried out (Tamayo, 2017). This cross-sectional research analyzes how the successor's formation influences a successful replacement in the family business's business management. This descriptive research shows the effects of the training that the successors receive from the founder to achieve success in the administration and continuity of family businesses.

This study collected data from 15 family businesses from different industries located in the southeast of Mexico. Figure 1 shows 15 companies for industry: eight services, five commercial, and 2 of production.

The study population was fifty respondents. The respondents' profile shown in figure 2 includes 15 founders, 16 successors, 6 advisors, and 13 executives.

In conducting this research, the data collection instrument was a closed-order questionnaire (Baena, 2009). Pearson's correlation coefficient uses to validate the questionnaire. The response options had an interquartile scale from one to four. The lower value answers reflect that the successor's training does not influence the business's continuity. The higher value answers reveal the influence that the successor training has to successfully replace the business management and achieve the family business's continuity.

This study includes the graph of the theoretical chi-square result of a pair of variables, with a theoretical inverse function: $p$-value vs. chi-square of 1 degree of freedom (González, Juárez \& Romero, 2016). 


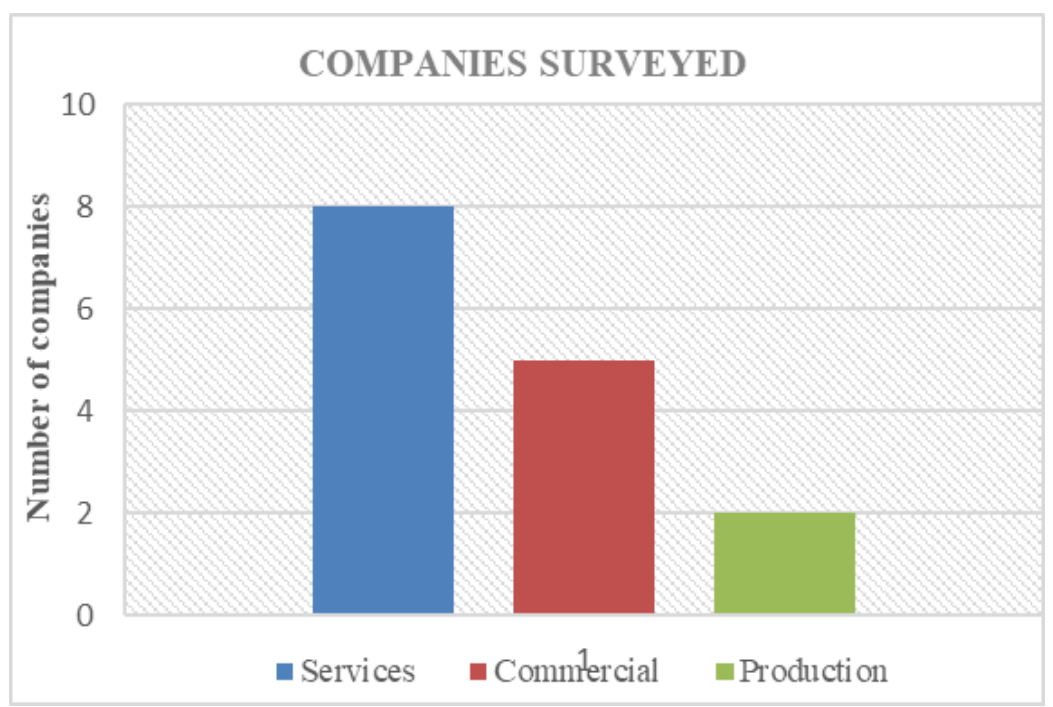

Figure 1. Graph of Surveyed Companies

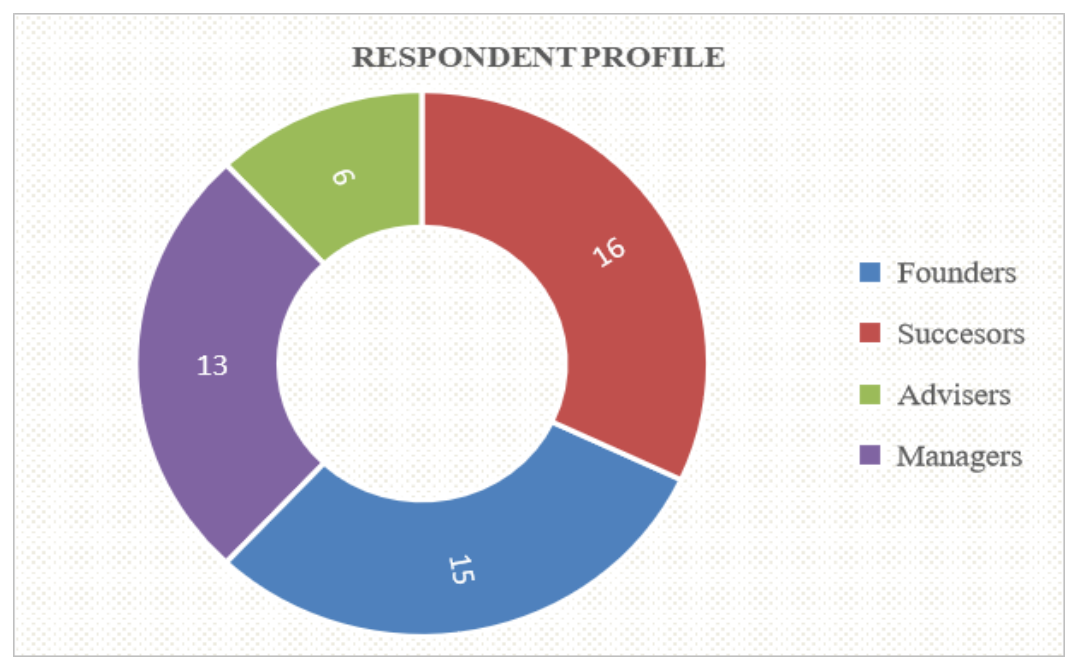

Figure 2. Graph of respondents 


\section{Results:}

Pearson's correlation (Table 1) uses to validate the instrument.

Table 1. Pearson's correlation of the items

\begin{tabular}{lrrrrrrrrrr}
\hline & ITEM 1 & ITEM2 & ITEM3 & ITEM4 & ITEM5 & ITEM6 & ITEM7 & ITEM 8 & ITEM9 & ITEM 10 \\
\hline ITEM 1 & 1 & & & & & & & & & \\
ITEM 2 & 0.1423693 & 1 & & & & & & & & \\
ITEM 3 & 0.1123048 & 0.0365 & 1 & & & & & & & \\
ITEM 4 & 0.0958367 & -0.028582 & 0.1755162 & 1 & & & & & & \\
ITEM 5 & -0.137374 & 0.0018603 & -0.0568 & -0.114371 & 1 & & & & & \\
ITEM 6 & -0.154043 & 0.1921861 & -0.020582 & -0.510199 & 0.2922056 & 1 & & & & \\
ITEM 7 & 0.1044262 & 0.5835261 & 0.0571954 & 0.0927175 & 0.0272078 & 0.1218961 & 1 & & \\
ITEM 8 & 0.1873172 & -0.129369 & -0.061718 & 0.0465116 & 0.0215699 & -0.092848 & -0.202721 & 1 & \\
ITEM 9 & 0.2815323 & 0.0115345 & 0.2317877 & 0.3276086 & -0.100371 & -0.114206 & 0.0826262 & 0.0700537 & 1 & 1 \\
ITEM 10 & -0.120942 & -0.085785 & 0.0344634 & -0.305986 & 0.0833093 & 0.2046085 & -0.134425 & 0.2704769 & -0.239155 & 1 \\
\hline
\end{tabular}

It can observe that there is no Pearson correlation in the items of the questionnaire.

Means that:

1. The elements are not repeating.

2. Respondents did not interpret items as the same or repeated.

3. The authors designed the items independently of each other.

4. The elements do not have a natural linear or polynomial relationship.

5. Items are naturally correlated. In this case, there was no Pearson correlation

The chi-square dependency test analyzes the relationship between successors' formation from their predecessors and family members' management to achieve their continuity. This test identifies the association between two categorical variables (Dangeti, 2017).

Table 1 shows the results of the raw values taken directly from the survey. Table 2 shows the expected values, and Table 3, the statistical chi-square values. In this specific case, questions 3 and 8 compare.

Question 3) Do you consider that family businesses' continuity depends on the founders preparing their successors to replace them?

Question 8) Do you think that family businesses' success will depend on the fact that, once their founders retire, the administration is in charge of family members? 
Table 2. Contingency, questions 3 and 8

\begin{tabular}{|c|c|c|c|c|}
\hline & \multicolumn{3}{|c|}{ Variable X. Formation of successors } \\
\hline & & Yes & Not & Total \\
\hline \multirow{3}{*}{$\begin{array}{c}\text { Variable } Y \\
\text { Success in management } \\
\text { by family members }\end{array}$} & Yes & 4 & 1 & 5 \\
\hline & Not & 13 & 32 & 45 \\
\hline & Total & 17 & 33 & 50 \\
\hline
\end{tabular}

Table 3. Expected values, questions 3 and 8

\begin{tabular}{|c|c|c|c|c|}
\hline & & \multicolumn{3}{|c|}{ Variable X. Formation of successors } \\
\hline & & Yes & Not & Total \\
\hline \multirow{3}{*}{$\begin{array}{c}\text { Variable Y } \\
\text { Success in management } \\
\text { by family members }\end{array}$} & Yes & 1.70 & 3.30 & 5 \\
\hline & Not & 15.30 & 29.70 & 45 \\
\hline & Total & 17 & 33 & 50 \\
\hline
\end{tabular}

Table 4. Statistical values, questions 3 and 8

\begin{tabular}{|c|c|c|c|c|}
\cline { 3 - 5 } \multicolumn{2}{c|}{} & \multicolumn{2}{c|}{ Variable X. Formation of successors } \\
\cline { 3 - 5 } & \multicolumn{1}{c|}{ Yes } & \multicolumn{1}{c|}{ Not } & \multicolumn{1}{c|}{ Total } \\
\hline $\begin{array}{c}\text { Variable Y } \\
\text { Success in management } \\
\text { by family members }\end{array}$ & Yes & 3.1118 & 1.6030 & 4.7148 \\
\cline { 2 - 5 } & Not & 0.3458 & 0.1781 & 0.5239 \\
\cline { 2 - 5 } & Total & 3.4575 & 1.7811 & $\mathbf{5 . 2 3 8 7}$ \\
\hline
\end{tabular}

The observed or experimental chi-square results show a value of 5.2387 (Table 4 ), while the theoretical chi-square value shows a value of 3.8415. Only for these two variables. The validated hypothesis is:

"The formation of successors is associated with success in the management by family members" or

"Success in the management by family members is due to the good training of successors."

In the results of these variables that form the study hypothesis, the calculated chi is above the theoretical chi and outside the standard Pearson curve for 1 degree of freedom (Figure 3 ).

Figure 4 shows the graph of six other dependent variables calculated by chi-square, with a $95 \%$ requirement, that is, with a theoretical p-value of 0.05 . Table 6 presents the results of these six variables associated and validated as research hypotheses. 


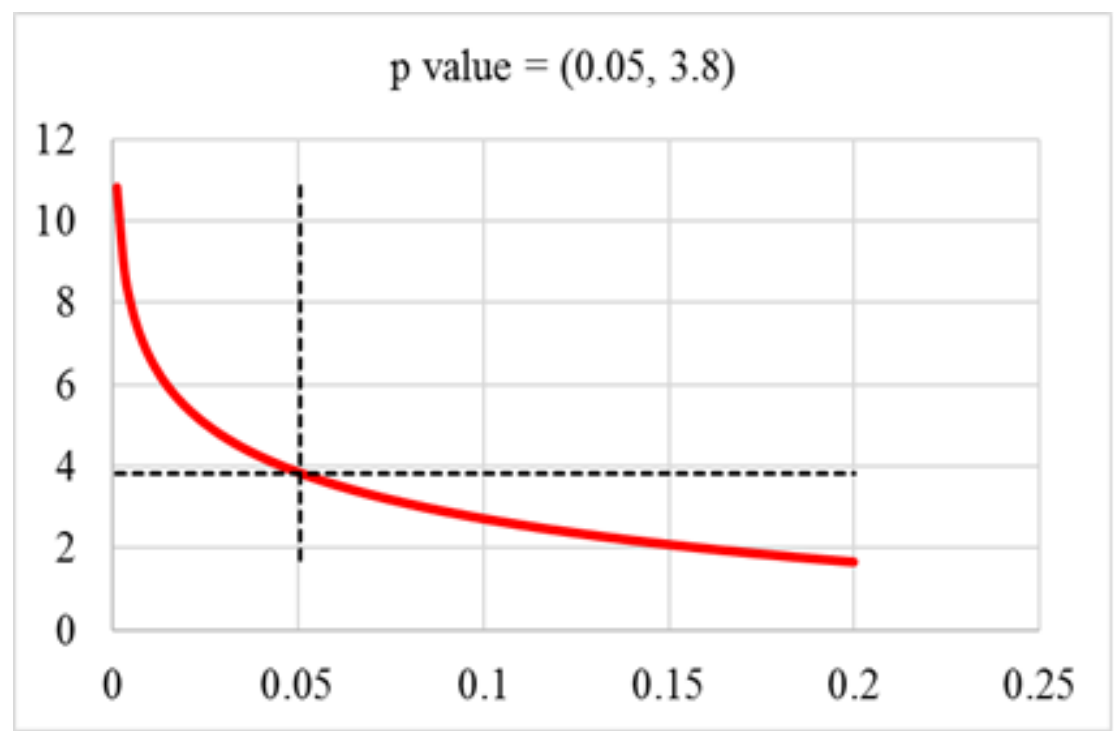

Figure 3. Graph of the theoretical inverse function: p-value (0.05) vs. chi-square (3.8) of 1 degree of freedom. This function is the one most used by researchers.

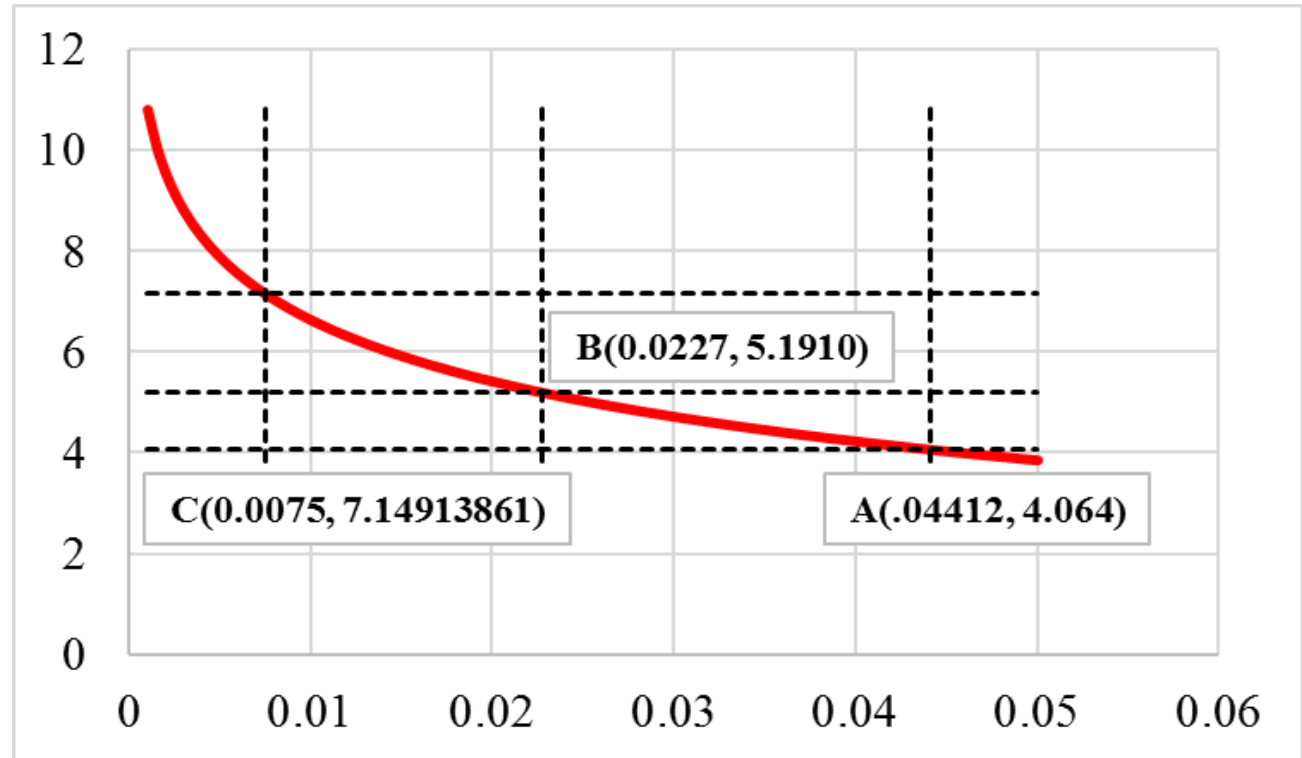

Figure 4. A plot of the p-value of each hypothesis validated with chi square, table 5. It observes all the variables of the validated hypotheses are associated with a reliability above $95 \%$ (which is the standard value figure 3 ) 
Table 5 presents the results of six other variables associated and validated as research hypotheses.

Table 5. Results of other dependent variables calculated by chi-square, with a requirement of $95 \%$ that is, with a theoretical p-value of 0.05

\begin{tabular}{|l|l|l|l|l|l|}
\hline $\begin{array}{l}\text { Independen } \\
\text { t Variable }\end{array}$ & $\begin{array}{l}\text { Dependent } \\
\text { Variable }\end{array}$ & $\begin{array}{l}\text { Observed } \\
\text { or } \\
\text { Calculated } \\
\text { Chi }\end{array}$ & $\begin{array}{l}\text { Theoretic } \\
\text { al Chi } \\
\text { P value } \\
\mathbf{( 0 . 0 5 )}\end{array}$ & Observation & $\begin{array}{l}\text { Validated } \\
\text { Hypothesis }\end{array}$ \\
\hline $\begin{array}{l}\text { Strategic } \\
\text { Planning } \\
(1)\end{array}$ & $\begin{array}{l}\text { Government } \\
\text { Corporate } \\
\mathbf{( 4 )}\end{array}$ & $\begin{array}{l}\mathbf{4 . 0 6 4 3} \\
\mathbf{( A )}\end{array}$ & $\mathbf{3 . 8 4 1 5}$ & $\begin{array}{l}\text { Variables } \\
\text { associated } \\
\text { with 96\% }\end{array}$ & $\begin{array}{l}\text { The strategic plan of } \\
\text { family businesses includes } \\
\text { corporate governance to } \\
\text { achieve their permanence. }\end{array}$ \\
\hline $\begin{array}{l}\text { Training } \\
\text { of successors } \\
(\mathbf{3})\end{array}$ & $\begin{array}{l}\text { Government } \\
\text { Corporate } \\
\mathbf{( 4 )}\end{array}$ & $\begin{array}{l}\mathbf{5 . 1 9 1 0} \\
\mathbf{( B )}\end{array}$ & $\mathbf{3 . 8 4 1 5}$ & $\begin{array}{l}\text { Variables } \\
\text { associated } \\
\text { with 98\% }\end{array}$ & $\begin{array}{l}\text { Founders of family } \\
\text { businesses preparing their } \\
\text { successors to replace them } \\
\text { also implement } \\
\text { institutional, corporate } \\
\text { governance. }\end{array}$ \\
\hline $\begin{array}{l}\text { Business } \\
\text { Institutional } \\
(\mathbf{2})\end{array}$ & $\begin{array}{l}\text { Administration by } \\
\text { staff with adequate } \\
\text { training and } \\
\text { knowledge. (7) }\end{array}$ & $\begin{array}{l}\mathbf{7 . 1 5 1 3} \\
\mathbf{( C )}\end{array}$ & $\mathbf{3 . 8 4 1 5}$ & $\begin{array}{l}\text { Variables } \\
\text { associated } \\
\text { with 99\% }\end{array}$ & $\begin{array}{l}\text { In institutional family } \\
\text { businesses, the } \\
\text { administration is in charge } \\
\text { of personnel with } \\
\text { adequate training and } \\
\text { knowledge. }\end{array}$ \\
\hline
\end{tabular}

\section{Conclusion}

Family businesses face their greatest challenge during generational change; succession represents their main problem, and a high percentage of these organizations do not survive this process. Various factors, such as the lack of a strategic plan and the implementation of corporate and institutional governance and adequate training of the successor, influence the generational transition's success.

The successor formation is a topic that authors from different countries have investigated over time; these authors approached this issue from different approaches. In Spain, studies show that three stages distinguish in the training of the future successor: the "remote" preparation stage, the "proximate" preparation, and the "in situ" (immediate) preparation. In Colombia, it was identified that the successors' preparation means developing the three dimensions of training: values, knowledge, and leadership. In Germany, the successor's training was analyzed, finding that the next leaders must train from three perspectives: development of hard skills, soft skills, and experience. In this same sense; in Mexico, nine founders were interviewed, who stated that the successor's formation would depend on the time and effort to educate the successors, instilling values and attitudes. Similarly, in Sweden, a study 
identified that the founding leader significantly affects the successor, except when the successor has had training elsewhere with an external organizational culture. Finally, the findings found in Indonesia, through an interview with nine successors, indicate that there are three main obstacles in the intergenerational transfer: the founder's trap, the rivalry between siblings and the passion of the next generation.

The influence that the family exerts on the company makes the formation of a successor essential to preserve the family legacy and keep business management in the family's hands. These companies' continuity depends mainly on the training received by his predecessor's successor to replace him when he decides to retire and hand over the baton. This research identified that the successor's formation influences the success of the family's government in the company to achieve its continuity.

According to the results generated, it can deduce that the variables of question 3, training of the successor, and 8 , success in the management and continuity of the family business, are associated.

- During this research, statistical tests use to identify six variables most dependent on each other. Items 3 and 4, 4 and 1, and 2 and 7 were found, with an association of $95 \%$ reliability in theoretical or critical chi and $100 \%$ reliability of observed or experimental chi, which forms study hypotheses for future lines research.

- The most important findings were the variables found by chi-square of items 4 and 1 that form the hypothesis "the family business's strategic plan includes corporate governance to achieve its permanence."

- The variables of items 3 and 4 form the hypothesis "the founders of family businesses who prepare their successors to replace them also implement an institutional, corporate government."

- Finally, the variables of items 2 and 7 form the hypothesis "in institutional family businesses; the administration is in charge of personnel with adequate training and knowledge."

It is concluded that the formation of the successor is a process that begins at home from an early age; In this stage, the successor learns and develops the values that will strengthen him as the leader of the family business. The successor's primary goal is to preserve the family legacy and keep the company's administration in the family's hands. Therefore, the family business's continuity depends mainly on the training received by their predecessors' successors to successfully replace them in business management when the time comes for their retirement.

This writing is a contribution to an issue that is underdeveloped in Mexico. It is necessary to point out that the study of family businesses' 
succession requires a scientific treatment and an in-depth and specific knowledge of the subject.

\section{Acknowledgments}

We are grateful to the group of Mexican Family Companies that answered the survey for the development of this study and the commitment they show to researching issues that contribute to this type of organization's continuity. Especially to the Founders, for their interest in the succession process experienced by family businesses in Mexico and particularly in the knowledge of a methodology and mechanisms to achieve generational success.

\section{References:}

1. Araya, A. (2011). La sucesión de empresas familiares costarricenses: factores de éxito y fracaso. Tesis Doctoral, Universidad de Valencia, España.

2. Baena, G. (2009). La influencia de la investigación en los procesos de la Administración. Investigación de operaciones (26(171),331-324). México. Fondo Nacional de Cultura Económica.

3. Basurto, C. A. M., \& Campos, J. L. T. (2017). La problemática de la sucesión en las empresas familiares. Revista Publicando, 4(11 (2), 294-305.

4. Belansteguigoitia Rius, L. (2013). Empresas familiares: Dinámica, equilibrio y consolidación. McGraw Hill.

5. Belausteguigoitia, Imanol. (1996). La Singular Dinámica de las Empresas Familiares en Latinoamérica. Artículo para la Universidad del Desarrollo.

6. Brenes, R.B., Madrigal K., \& Molina N.G.E. (2006). Family business structure and succession: Critical topics in Latin American experience. Journal of Business Research 59, 372-374

7. Cherem, S. (2008). Al grano vida y vision de los fundadores de bimbo. México: Khalida editores.

8. Davis, S. P. \& Harveston, P. D. (1998). The influen- ce of family on the family business succession process: A multigenerational perspective. Entrepreneurship Theory and Practice, 22 (3), 31-53.

9. Dangeti, P. (2017). Statistics for machine learning. Packt Publishing Ltd.

10. Durán M.C. (2019, Junio 24), Continuidad, prioridad de las empresas familiares. FORBES, México, 2019

11. Recuperado de https://www.forbes.com.mx/continuidad-prioridad-enempresas-familiares/. 
12. Drennan, J., Kennedy, J. y Renfrow, P. (2005). Im- pact of childhood experiences on the develop- ment of entrepreneurial intentions. International Journal of Entrepreneurship and Innovation, 6 (4), 231238.

13. Fuad, M., Sudarma, M., \& Irianto, G. (2019). Exploration of obstacles faced by successors in the intergenerational transition process of family business. Jurnal Aplikasi Manajemen, 17(1), 20-29.Gallo, M. (1995). Empresa familiar: Textos y casos. Barcelona: Editorial Praxis.

14. Gallo, M. Á. (1998). La sucesión en la empresa familiar (No. 12). " la Caixa".

15. Gaona Tamez, L. L., de la Garza Cienfuegos, S. P., \& Hernández Sandoval, R. H. (2014). El Sucesor, Figura Clave en el Éxito de La Empresa Familiar (The Successor, Key Figure in the Success of the Company ousehold). Revista Internacional Administración \& Finanzas, 7(3), 57-67.

16. Gutiérrez, M. C. P., Gómez, L. L. B., Beas, J. F. H., \& Ortega, A. T. (2018).

17. Problemas que enfrentan las empresas familiares en el proceso de sucesión. DUCATECONCIENCIENCIA, 17(18).D

18. González, M. A. M., Benítez, H. A. U., \& Tamayo, E. J. G. (2017). Factores determinantes del éxito del proceso sucesorio en empresas familiares de Dzityá, Yucatán. Red Internacional de Investigadores en Competitividad, 4(1).

19. González, M., Juárez B., Silka \& Romero O. Moisés, (2016). Metodología de la redacción Científica. Un enfoque cuántico Hamiltoniano. Columbia S.C. U.S.A.

20. Hollerbach, A. (2012). The Important Role of the Successor within the Family Succession Process. Ekonomika a Management, 2012(1), 2834.

21. IPADE, 2019. "Situación y Progreso de las Empresas Familiares para lograr su Continuidad". Centro de Investigación para Familias de Empresarios, CIFEM-BBVA. Recuperado de https://www.bbva.com/es/mx/algunos-desafios-que-tienen-lasempresas-familiares-para-lograr-su-continuidad/

22. Lambrech, J. (2005). Multigenerational transition in the family business: A new explanatory model. Family Business Review, 18 (4), 267-282.

23. Leandro, A. A. (2017). Modelos de planeación estratégica en las empresas familiares. Tec. Empresarial, 11(1), ág-23.

24. Leach, P. (1993). La empresa familiar. Barcelona: Ediciones Granica.

25. Longenecker, J. y Schoen, J. (1978). Management succession in the family business. Journal of Small Business Management, 16 (3), 1-6. 
26. Tamayo, Tamayo, M. (2017) Métodos Investigación Científica en la Administración. Revista Investigación y Administración, pag.228-229.

27. Pymes (2014, 6 de Junio) ¿Cómo planificar la continuidad de su empresa familiar? El financiero, recuperado de https://www.elfinancierocr.com/pymes/como-planificar-lacontinuidad-de-suempresafamiliar/sglqahxsmjeo7czf7ldn27dype/story/.

28. Posso, M. L. (2008). Elementos del proceso de formación de descendientes antes de su vinculación a la empresa familiar: un estudio de casos colombianos. Cuadernos de Administración, 21(37).

29. Quejada Pérez, R. F., \& Ávila Gutiérrez, J. N. (2016). Empresas familiares: Conceptos, teorías y estructuras. Revista EAN, (81), 149158.

30. Schlepphorst, S., \& Moog, P., (2014). Left in the dark: Family successors' requirement profiles in the family business succession process. Journal of Family Business Strategy 5 (2014) 358-371

31. Tápies, J. (2011). Familia empresaria. LID Editorial.

32. Vassiliadis, S., Siakas, K., \& Vassiliadis, A. (2015). Passing the baton to the next generation of the Greek family businesses. Procedia Economics and Finance, 33, 528-534.

33. Visser, A., \& Lu, D. (2019). Incumbent leaders and their effect on the successor generation in family business SME's.

34. Walsh, G. (2011). Family Business Succession. Managing the AllImportant Family Component, KPMG.

35. Ward, J. L. (1994). Cómo desarrollar la empresa familiar. Buenos Aires: El Ateneo.

36. Ward, J. L. \& Sorenson, L. S. (1988). Turning children into managers. Nation's Business, 76 (8), 49. 


\section{Annexed}

\section{KEY FACTORS AFFECTING THE CONTINUITY OF THE FAMILY BUSINESS}

\begin{tabular}{|c|c|c|c|c|c|}
\hline & \multicolumn{3}{|c|}{$\begin{array}{l}\text { We appreciate your time and kindness in answering these questions. } \\
\text { The purposes of this survey are exclusively academic. }\end{array}$} & \multicolumn{2}{|c|}{$\begin{array}{l}\text { Respondent } \\
\text { Profile }\end{array}$} \\
\hline \multicolumn{4}{|c|}{$\begin{array}{l}\text { In the yellow box, please mention the kind of respondents to which you belong: } \\
\text { Founder, Advisor, Successor, Director, Advisor. }\end{array}$} & & \\
\hline & QUESTIONNAIRE & 1 & 2 & 3 & 4 \\
\hline & PLEASE MARK YOUR ANSWER WITH AN X & Never & Sometimes & $\begin{array}{l}\text { Most of } \\
\text { the time }\end{array}$ & Always \\
\hline 1 & $\begin{array}{l}\text { Do you consider that strategic planning is important in } \\
\text { family businesses? }\end{array}$ & & & & \\
\hline 2 & Do you consider family businesses are institutional? & & & & \\
\hline 3 & $\begin{array}{l}\text { Do you consider that family businesses' continuity } \\
\text { depends on the founders preparing their successors to } \\
\text { replace them? }\end{array}$ & & & & \\
\hline 4 & $\begin{array}{l}\text { Do you consider that family businesses are managed } \\
\text { through corporate, institutional governance? }\end{array}$ & & & & \\
\hline 5 & $\begin{array}{l}\text { Do you consider that family businesses are more } \\
\text { successful when their founders operate them? }\end{array}$ & & & & \\
\hline 6 & $\begin{array}{l}\text { How often, in family businesses, are senior positions } \\
\text { assigned to family members? }\end{array}$ & & & & \\
\hline 7 & $\begin{array}{l}\text { Do you consider that administration is given to people } \\
\text { with the right knowledge and preparation in family } \\
\text { businesses? }\end{array}$ & & & & \\
\hline 8 & $\begin{array}{l}\text { Do you think that family businesses' success will } \\
\text { depend on the managem ent being carried out by family } \\
\text { members? }\end{array}$ & & & & \\
\hline 9 & $\begin{array}{l}\text { Do you consider that the creation of a family protocol } \\
\text { guarantees the continuity of family businesses? }\end{array}$ & & & & \\
\hline 10 & $\begin{array}{l}\text { How often, in family businesses, do successors take } \\
\text { over until the death of the founders? }\end{array}$ & & & & \\
\hline
\end{tabular}

